\title{
The Inhibitory and Catalyzing Effects of Different Materials on the Thermal Decomposition of Potassium Peroxydisulphate in Aqueous Solution at $70{ }^{\circ} \mathrm{C}$
}

\author{
M. J. A. Abualreish ${ }^{1,2}$ \\ ${ }^{1}$ Department of Chemistry, Faculty of Science, Northern Boarders University, Arar, Kingdom of Saudi Arabia \\ (current address) \\ ${ }^{2}$ Department of Chemistry, Faculty of Science and Technology, Omdurman Islamic University, Sudan \\ (permanent address) \\ Correspondence: M. J. A. Abualreish, Department of Chemistry, Faculty of Science, Northern Boarders \\ University, Arar, Kingdom of Saudi Arabia. E-mail: Mustjeed_2008@hotmail.com
}

Received: January 17, 2012 Accepted: February 6, 2012 Online Published: May 27, 2012

doi:10.5539/ijc.v4n3p121 URL: http://dx.doi.org/10.5539/ijc.v4n3p121

\begin{abstract}
The present study is an investigation of the inhibitory effect of halides ions and the mineral salt potassium sulphate; and the catalyzing influences of electrolytes; non - electrolytes and the mineral salt mercuric chloride on the thermal decomposition of potassium peroxydisulphate at $70{ }^{\circ} \mathrm{C}$. The study showed that the specific inhibitory effect of halides ions on the thermal decomposition is in the order: $\mathrm{F}<\mathrm{Cl}<\mathrm{Br}<\mathrm{I}$; while the catalyzing influences of electrolytes and non - electrolytes on the decomposition in the order: $\mathrm{HCl}>\mathrm{KCl}>$ $\mathrm{H}_{2} \mathrm{SO}_{4}>\mathrm{K}_{2} \mathrm{SO}_{4}>$ Urea. It was also found that potassium sulphate acts as an inhibitor on the thermal decomposition; while mercuric chloride exhibits a catalyzing influence on the decomposition.
\end{abstract}

Keywords: inhibitory effect, catalyzing influence, thermal decomposition, potassium peroxydisulphate

\section{Introduction}

The thermal decomposition of potassium peroxydisulphate was the subject of study of many workers (Morgan \& Christ, 1927; Fronaeus \& Ostman, 1955; Kolthoff \& Miller, 1951), all they suggested that the decomposition follows a first order kinetics. Early workers (Green \& Mason, 1910) studying the thermal decomposition of potassium peroxydisulphate found that the decomposition in aqueous solution was accelerated by rise of temperature and depends on the concentration of solution. Levi and Migliorini (Levi, Migliorini, \& Gazz, 1963) observed that peroxydisulphate solutions which were stable at $35^{\circ} \mathrm{C}$ are decompose catalytically by the hydrogen and the hydroxyl ions as well as platinum black and lead. Fronaeus and Ostman (Fronaeus \& Ostman, 1955) and Kolthoff and Miller (Kolthoff \& Miller, 1951) showed that the rate constant of the decomposition was independent of the ionic strength but in acid solution there is a negative salt effect. Vasudeva (Vasudeva, 1969) noticed that in aqueous solution potassium peroxydisulphate decomposes slowly at $60{ }^{\circ} \mathrm{C}$ and the decomposition shows auto-inhibition in the beginning and then follows first order kinetics.

Bartlett and Cottman (1949) suggested for the uncatalyzed thermal decomposition the following chain mechanism:

$$
\begin{aligned}
\mathrm{S}_{2} \mathrm{O}_{8}^{=} & \leftrightarrow \mathrm{SOO}^{--}{ }_{4} \\
\mathrm{SO}^{-}{ }_{4}+\mathrm{H}_{2} \mathrm{O} & \leftrightarrow \mathrm{HSO}_{4}^{-}+\mathrm{OH} \\
\mathrm{OH}^{-}+\mathrm{S}_{2} \mathrm{O}^{-}{ }_{8} & \leftrightarrow \mathrm{HSO}_{4}^{-}+\mathrm{SO}^{-}{ }_{4}+1 / 2 \mathrm{O}_{2} \\
\mathrm{SO}^{-}{ }_{4}+\mathrm{OH} & \leftrightarrow \mathrm{SO}^{-}{ }_{4}+1 / 2 \mathrm{O}_{2}+\mathrm{H}^{+}
\end{aligned}
$$

Another mechanisms for the uncatalyzed thermal decomposition were suggested by Fronaeus and Ostman (1955) and Levitt (1953).

\section{Experimental}

All chemicals used were AnalaR grade. All solutions were prepared according to the usual analytical procedures. 
Deionized water was used in all kinetic runs. Since the reaction does not take place to any measurable extent at room temperature $\left(\mathbf{t}_{1 / 2}=\right.$ one month) (Vasudeva, 1969), the temperature used was $70^{\circ} \mathrm{C}$. The iodometric method was used for the analysis and estimation of unreacted peroxydisulphate $\left[\mathbf{S}_{\mathbf{2}} \mathbf{O}_{\mathbf{8}}{ }_{\mathbf{8}}\right]$ which is a modification of the method used by Bartlett and Cottman (Bartlett \& Cotman, 1949) and Rosin (1946).

\section{Results and Discussion}

Tables (1) and (2) show the inhibitory effect of the metal halides, potassium chloride and potassium bromide on the thermal decomposition of potassium peroxydisulphate at $70^{\circ} \mathrm{C}$ in which the concentration of the metal halides were 0.1 and 0.2 mole/ $/ 1$ while that of peroxydisulphate was kept constant at 0.01 mole/l. Results were represented graphically in Figure (1).

Table 1. The inhibitory effect of the metal halides, potassium chloride and potassium bromide on the thermal decomposition of potassium peroxydisulphate at $70^{\circ} \mathrm{C}$

\begin{tabular}{ccccccccccc}
\hline $\begin{array}{c}\text { Time } \\
\mathrm{min}\end{array}$ & None & $\begin{array}{c}\mathrm{X} \\
\mathrm{ml}\end{array}$ & $\begin{array}{c}\mathrm{KCl} \\
0.1 \mathrm{M}\end{array}$ & $\begin{array}{c}\mathrm{X} \\
\mathrm{ml}\end{array}$ & $\begin{array}{c}\mathrm{KCl} \\
0.2 \mathrm{M}\end{array}$ & $\begin{array}{c}\mathrm{X} \\
\mathrm{ml}\end{array}$ & $\begin{array}{c}\mathrm{KBr} \\
0.1 \mathrm{M}\end{array}$ & $\begin{array}{c}\mathrm{X} \\
\mathrm{ml}\end{array}$ & $\begin{array}{c}\mathrm{KBr} \\
0.2 \mathrm{M}\end{array}$ & $\begin{array}{c}\mathrm{X} \\
\mathrm{ml}\end{array}$ \\
\hline 0 & 15.0 & & 15.0 & & 15.0 & & 15.0 & & 15.0 & \\
20 & 13.7 & 1.3 & 14.8 & 0.2 & 14.7 & 0.3 & 14.6 & 0.4 & 14.4 & 0.6 \\
40 & 13.3 & 1.7 & 14.6 & 0.4 & 14.4 & 0.6 & 14.3 & 0.7 & 14.0 & 1.0 \\
60 & 13.1 & 1.9 & 14.4 & 0.6 & 14.2 & 0.8 & 14.0 & 1.0 & 13.5 & 1.5 \\
80 & 12.7 & 2.3 & 14.2 & 0.8 & 14.0 & 1.0 & 13.7 & 1.3 & 13.3 & 1.7 \\
100 & 12.6 & 2.4 & 14.0 & 1.0 & 13.7 & 1.3 & 13.4 & 1.6 & 13.1 & 1.9 \\
120 & 12.3 & 2.7 & 13.8 & 1.2 & 13.5 & 1.5 & 13.2 & 1.8 & 12.9 & 2.1 \\
140 & 12.0 & 3.0 & 13.5 & 1.5 & 13.0 & 2.0 & 12.7 & 2.3 & 12.5 & 2.5 \\
160 & 11.6 & 3.4 & 13.0 & 2.0 & 12.7 & 2.3 & 12.1 & 2.9 & 11.9 & 3.1 \\
\hline
\end{tabular}

Table 2. Summary of the rate $(\mathrm{R})$ and the observed rate constant $\mathrm{k}_{\mathrm{O}}$ of the inhibitory effect of halides ions

\begin{tabular}{cccccc}
\hline & None & $\mathrm{KCl}$ & $\mathrm{KCl}$ & $\mathrm{KBr}$ & $\mathrm{KBr}$ \\
& & $0.1 \mathrm{M}$ & $0.2 \mathrm{M}$ & $0.1 \mathrm{M}$ & $0.2 \mathrm{M}$ \\
\hline $\mathbf{1 0}^{\mathbf{6}} \mathbf{R}$ & 0.2219 & 0.1581 & 0.1594 & 0.2134 & 0.2365 \\
$\mathrm{~mole} / \mathrm{l} / \mathrm{sec}$ & & & & & \\
$\mathbf{1 0}^{\mathbf{5}}$ & 2.64 & 1.66 & 1.75 & 1.99 & 2.61 \\
$\mathbf{k}_{\mathbf{0}} \mathrm{sec}^{-1}$ & & & & & \\
\hline
\end{tabular}

The inhibitory effect of iodide ion could not be investigated because even at very low concentration of KI a reaction between $\mathrm{KI}$ and $\mathrm{K}_{2} \mathrm{~S}_{2} \mathrm{O}_{8}$ took place, in the case of $\mathrm{KBr}$ also a concentration equal to that of $\mathrm{KCl}$ could not be used as bromine was liberated due to the interaction of $\mathrm{KBr}$ with $\mathrm{K}_{2} \mathrm{~S}_{2} \mathrm{O}_{8}$, this leads to the conclusion that the specific inhibitory effect of $\mathrm{Br}$ ion is greater than that of $\mathrm{Cl}$ ion.

Comparing the curves in Figure (1) corresponding to the four different initial concentrations of halides indicate that the specific inhibitory effect of halides ions is in the order $\mathrm{F}<\mathrm{Cl}<\mathrm{Br}<\mathrm{I}$ and the specific inhibitory increased with increasing concentration. So we can conclude that the inhibitory effect of halides ions is not a proper salt effect and it is an instance of specific ionic effect, because when we used a very high concentration of potassium sulphate the decrease in the rate constant is much less than in the case of any halide ion.

Tables (3) and (4) show the influence of the mineral salt potassium sulphate on the thermal decomposition of $0.01 \mathrm{~mole} / \mathrm{l}$ potassium peroxydisulphate at $70{ }^{\circ} \mathrm{C}$. Results were represented graphically in Figure (2). 


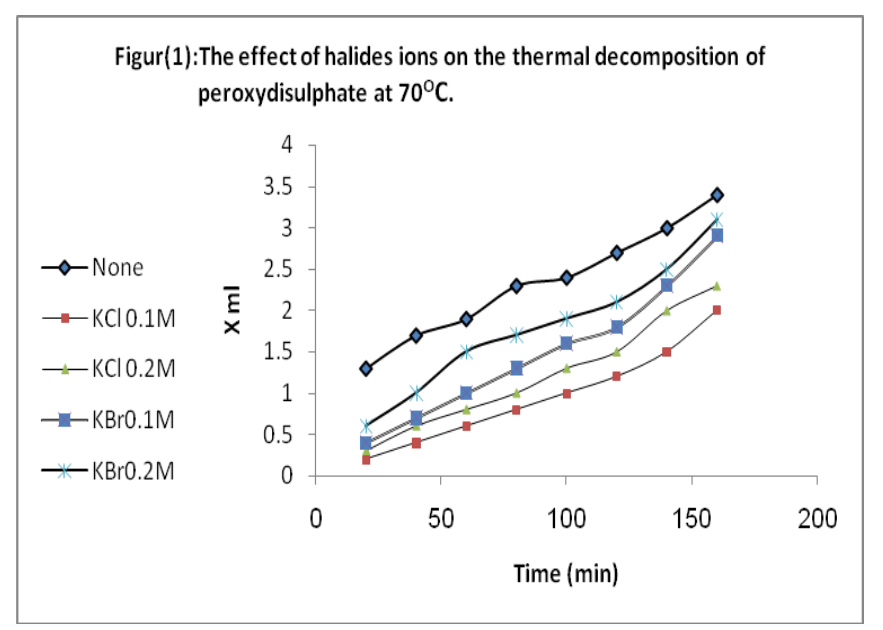

Figure 1. The effect of halides ions on the thermal decomposition of peroxydisulphate at $70{ }^{\circ} \mathrm{C}$

Table 3. The influence of the mineral salt potassium sulphate on the thermal decomposition of potassium peroxydisulphate at $70^{\circ} \mathrm{C}$

\begin{tabular}{ccccccccc}
\hline $\begin{array}{c}\text { Time } \\
\min \end{array}$ & None & $\begin{array}{c}\mathrm{X} \\
\mathrm{ml}\end{array}$ & $\begin{array}{c}\mathrm{K}_{2} \mathrm{SO}_{4} \\
0.01 \mathrm{M}\end{array}$ & $\begin{array}{c}\mathrm{X} \\
\mathrm{ml}\end{array}$ & $\begin{array}{c}\mathrm{K}_{2} \mathrm{SO}_{4} \\
0.03 \mathrm{M}\end{array}$ & $\begin{array}{c}\mathrm{X} \\
\mathrm{ml}\end{array}$ & $\begin{array}{c}\mathrm{K}_{2} \mathrm{SO}_{4} \\
0.05 \mathrm{M}\end{array}$ & $\begin{array}{c}\mathrm{X} \\
\mathrm{ml}\end{array}$ \\
\hline 0 & 15.0 & & 15.0 & & 15.0 & & 15.0 & \\
20 & 14.8 & 0.2 & 14.0 & 1.0 & 13.3 & 1.7 & 12.9 & 2.1 \\
40 & 14.1 & 0.9 & 13.4 & 1.6 & 12.8 & 2.2 & 12.1 & 2.9 \\
60 & 13.7 & 1.3 & 12.7 & 2.3 & 12.2 & 2.8 & 11.6 & 3.4 \\
80 & 13.3 & 1.7 & 12.5 & 2.5 & 11.8 & 3.2 & 11.1 & 3.9 \\
100 & 12.9 & 2.1 & 12.1 & 2.9 & 11.2 & 3.8 & 10.2 & 4.8 \\
120 & 12.5 & 2.5 & 11.9 & 3.1 & 10.7 & 4.3 & 9.2 & 5.8 \\
140 & 12.3 & 2.7 & 11.7 & 3.3 & 10.0 & 5 & 9.0 & 6 \\
160 & 12.0 & 3 & 11.5 & 3.5 & 9.7 & 5.3 & 8.9 & 6.1 \\
\hline
\end{tabular}

Table 4. Summary of the rate $(\mathrm{R})$ and the observed rate constant $\mathrm{k}_{\mathrm{O}}$ due to the influence of the mineral salt potassium sulphate on the thermal decomposition of potassium peroxydisulphate at $70{ }^{\circ} \mathrm{C}$

\begin{tabular}{ccccc}
\hline & None & $\mathrm{K}_{2} \mathrm{SO}_{4}$ & $\mathrm{~K}_{2} \mathrm{SO}_{4}$ & $\mathrm{~K}_{2} \mathrm{SO}_{4}$ \\
& & $0.01 \mathrm{M}$ & $0.03 \mathrm{M}$ & $0.05 \mathrm{M}$ \\
\hline $\begin{array}{c}\mathbf{1 0}^{6} \mathbf{R} \\
\mathrm{mole} / 1 / \mathrm{sec} \\
\mathbf{1 0}^{5} \mathbf{k}_{\mathbf{0}}\end{array}$ & 0.2219 & 0.4240 & 0.3677 & 0.2427 \\
$\mathrm{sec}^{-1}$ & 2.64 & 5.60 & 4.75 & 4.14 \\
\hline
\end{tabular}




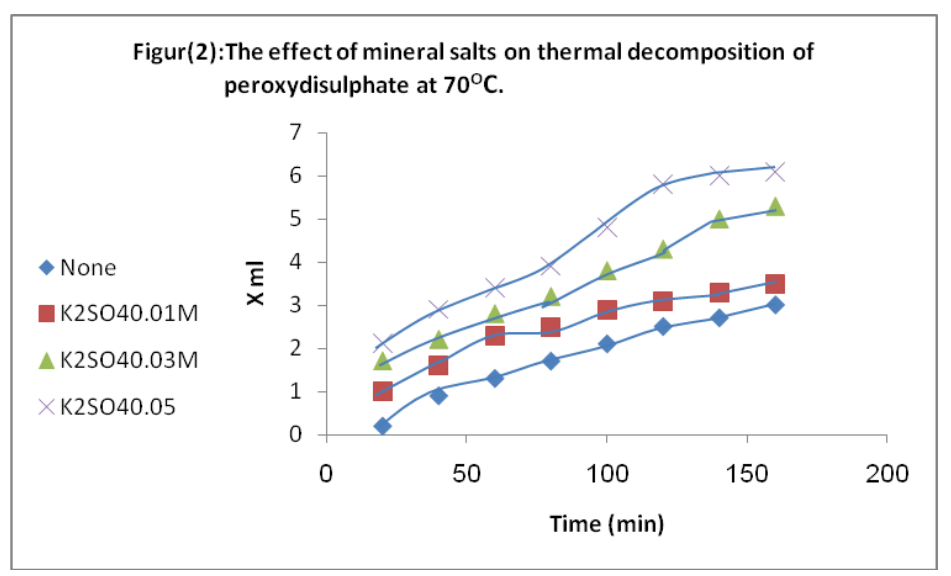

Figure 2. The effect of mineral salts on the thermal decomposition of peroxydisulphate at $70{ }^{\circ} \mathrm{C}$

Tables (5) and (6) show the effect of the electrolytes, hydrochloric acid, potassium chloride, sulphuric acid and potassium sulphate and the non-electrolyte urea on the thermal decomposition of potassium peroxydisulphate at $70^{\circ} \mathrm{C}$ in which its concentration was kept constant at $\mathbf{0 . 0 1}$ mole/l . Results were represented graphically in Figure (3).

Table 5. The effect of electrolytes and non-electrolyte on the thermal decomposition of potassium peroxydisulphate at $70^{\circ} \mathrm{C}$

\begin{tabular}{ccccccccccc}
\hline $\begin{array}{c}\text { Time } \\
\min \end{array}$ & $\begin{array}{c}\mathrm{H}_{2} \mathrm{SO}_{4} \\
0.05 \mathrm{M}\end{array}$ & $\begin{array}{c}\mathrm{X} \\
\mathrm{ml}\end{array}$ & $\begin{array}{c}\mathrm{KCl} \\
0.05 \mathrm{M}\end{array}$ & $\begin{array}{c}\mathrm{X} \\
\mathrm{ml}\end{array}$ & $\begin{array}{c}\mathrm{K}_{2} \mathrm{SO}_{4} \\
0.05 \mathrm{M}\end{array}$ & $\begin{array}{c}\mathrm{X} \\
\mathrm{ml}\end{array}$ & $\begin{array}{c}\mathrm{Urea} \\
0.05 \mathrm{M}\end{array}$ & $\begin{array}{c}\mathrm{X} \\
\mathrm{ml}\end{array}$ & $\begin{array}{c}\mathrm{HCl} \\
0.05 \mathrm{M}\end{array}$ & $\begin{array}{c}\mathrm{X} \\
\mathrm{ml}\end{array}$ \\
\hline 0 & 15.0 & & 15.0 & & 15.0 & & 15.0 & & 15.0 & \\
20 & 14.6 & 0.4 & 14.2 & 0.8 & 14.8 & 0.2 & 14.8 & 0.2 & 13.9 & 1.1 \\
40 & 14.1 & 0.9 & 14.7 & 1.3 & 14.6 & 0.4 & 14.7 & 0.3 & 13.3 & 1.7 \\
60 & 13.8 & 1.2 & 13.3 & 1.7 & 14.4 & 0.6 & 14.5 & 0.5 & 12.9 & 2.1 \\
80 & 13.2 & 1.8 & 12.8 & 2.2 & 14.1 & 0.9 & 14.3 & 0.7 & 12.3 & 2.7 \\
100 & 12.8 & 2.2 & 12.4 & 2.6 & 13.7 & 1.3 & 14.1 & 0.9 & 12.0 & 3 \\
120 & 12.3 & 2.7 & 11.8 & 3.2 & 13.0 & 2 & 13.6 & 1.4 & 11.5 & 3.5 \\
140 & 12.0 & 3 & 11.4 & 3.6 & 12.8 & 2.2 & 13.2 & 1.8 & 11.1 & 3.9 \\
160 & 11.3 & 3.7 & 10.9 & 4.1 & 12.2 & 2.8 & 12.7 & 2.3 & 10.5 & 4.5 \\
\hline
\end{tabular}

Table 6. Summary of the rate $(\mathrm{R})$ and the observed rate constant $\mathrm{k}_{\mathrm{O}}$ of the effect of electrolytes and nonelectrolytes

\begin{tabular}{lllllll}
\hline & None & $\mathrm{HCl}$ & $\mathrm{KCl}$ & $\mathrm{H}_{2} \mathrm{SO}_{4}$ & $\mathrm{~K}_{2} \mathrm{SO}_{4}$ & Urea \\
& & $0.05 \mathrm{M}$ & $0.05 \mathrm{M}$ & $0.05 \mathrm{M}$ & $0.05 \mathrm{M}$ & $0.05 \mathrm{M}$ \\
\hline $\begin{array}{l}\mathbf{1 0}^{\mathbf{6}} \mathbf{R} \\
\mathrm{mole} / \mathrm{l} / \mathrm{sec}\end{array}$ & 0.2219 & 0.2885 & 0.2844 & 0.2636 & 0.2154 & 0.1746 \\
$\begin{array}{l}\mathbf{1 0}^{\mathbf{5}} \mathbf{k}_{\mathbf{0}} \\
\sec ^{-1}\end{array}$ & 2.64 & 3.30 & 2.80 & 2.75 & 1.99 & 1.40 \\
\hline
\end{tabular}




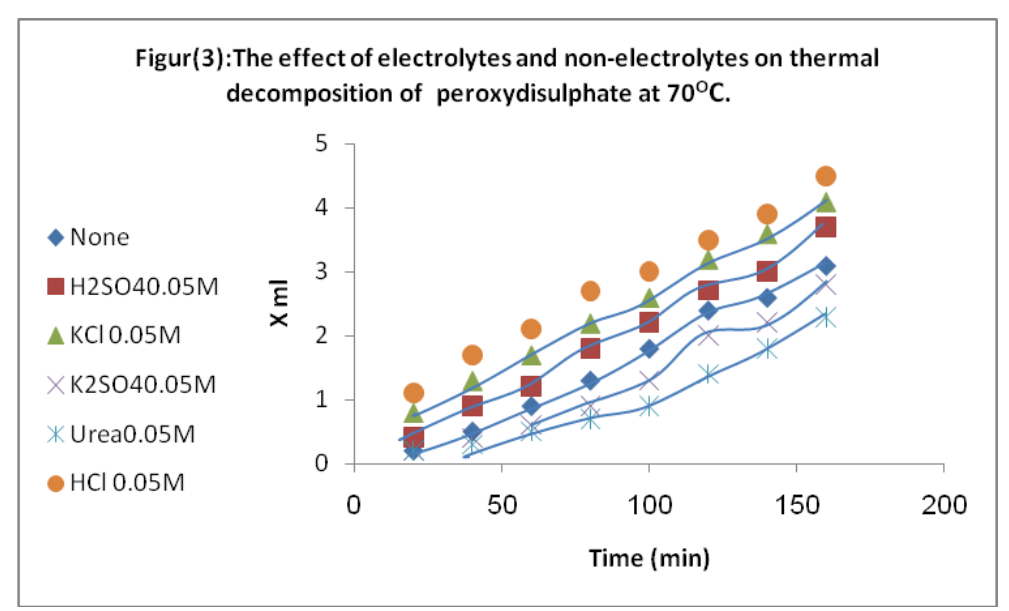

Figure 3. The effect of electrolytes and non-electrolytes on the thermal decomposition of peroxydisulphate at $70^{\circ} \mathrm{C}$

Tables (7) and (8) show the influence of mercuric chloride on the thermal decomposition of 0.01 mole/l potassium peroxydisulphate at $70{ }^{\circ} \mathrm{C}$. Results were represented graphically in Figure (4).

Table 7. The influence of mercuric chloride on the thermal decomposition of potassium peroxydisulphate at 70 ${ }^{\circ} \mathrm{C}$

\begin{tabular}{ccccccccc}
\hline $\begin{array}{c}\text { Time } \\
\min \end{array}$ & None & $\begin{array}{c}\mathrm{X} \\
\mathrm{ml}\end{array}$ & $\begin{array}{c}\mathrm{HgCl}_{2} \\
0.002 \mathrm{M}\end{array}$ & $\begin{array}{c}\mathrm{X} \\
\mathrm{ml}\end{array}$ & $\begin{array}{c}\mathrm{HgCl}_{2} \\
0.005 \mathrm{M}\end{array}$ & $\begin{array}{c}\mathrm{X} \\
\mathrm{ml}\end{array}$ & $\begin{array}{c}\mathrm{HgCl}_{2} \\
0.01 \mathrm{M}\end{array}$ & $\begin{array}{c}\mathrm{X} \\
\mathrm{ml}\end{array}$ \\
\hline 0 & 15.0 & & 15.0 & & 15.0 & & 15.0 & \\
20 & 13.8 & 1.2 & 14.2 & 0.8 & 14.5 & 0.5 & 13.2 & 1.8 \\
40 & 13.3 & 1.7 & 13.9 & 1.1 & 14.2 & 0.8 & 12.9 & 2.1 \\
60 & 13.0 & 2 & 13.4 & 1.6 & 13.8 & 1.2 & 12.5 & 2.5 \\
80 & 12.7 & 2.3 & 13.1 & 1.9 & 13.5 & 1.5 & 12.2 & 2.8 \\
100 & 12.5 & 2.5 & 12.9 & 2.1 & 13.2 & 1.8 & 12.0 & 3 \\
120 & 12.1 & 2.9 & 12.5 & 2.5 & 12.8 & 2.2 & 11.7 & 3.3 \\
140 & 11.6 & 3.4 & 12.0 & 3 & 12.4 & 2.6 & 11.3 & 3.7 \\
160 & 11.0 & 4 & 11.3 & 3.7 & 11.9 & 3.1 & 10.6 & 4.4 \\
\hline
\end{tabular}

Table 8. Summary of the rate $(\mathrm{R})$ and the observed rate constant $\mathrm{k}_{\mathrm{o}}$ due to the influence of mercuric chloride on the thermal decomposition of potassium peroxydisulphate at $70^{\circ} \mathrm{C}$

\begin{tabular}{ccccc}
\hline & None & $\begin{array}{c}\mathrm{HgCl}_{2} \\
0.002 \mathrm{M}\end{array}$ & $\begin{array}{c}\mathrm{HgCl}_{2} \\
0.005 \mathrm{M}\end{array}$ & $\begin{array}{c}\mathrm{HgCl}_{2} \\
0.01 \mathrm{M}\end{array}$ \\
\hline $\begin{array}{c}\mathbf{1 0}^{\mathbf{6}} \mathbf{R} \\
\mathrm{mole} / \mathrm{l} / \mathrm{sec} \\
\mathbf{1 0}^{5} \mathbf{k}_{\mathbf{0}}\end{array}$ & 0.2219 & 0.2573 & 0.2572 & 0.3469 \\
$\mathrm{sec}^{-1}$ & 2.64 & 2.68 & 2.83 & 4.19 \\
\hline
\end{tabular}




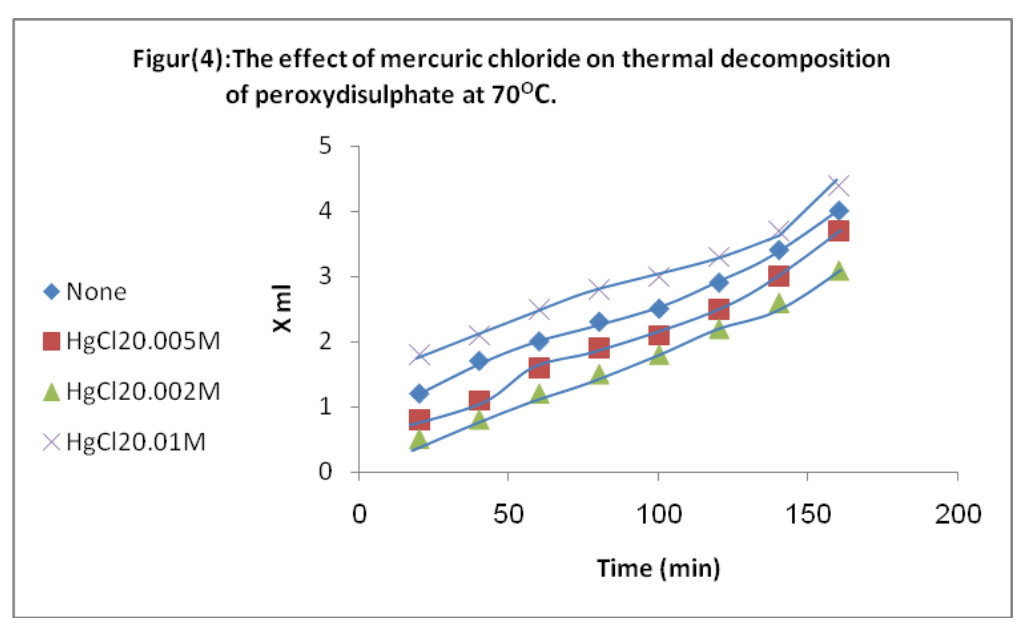

Figure 4. The effect of mercuric chloride on the thermal decomposition of peroxydisulphate at $70{ }^{\circ} \mathrm{C}$

\section{Conclusions}

Comparing the curves in Figure (1) corresponding to the four different initial concentrations of halides indicate that the specific inhibitory effect of halides ions is in the order $\mathrm{F}<\mathrm{Cl}<\mathrm{Br}<\mathrm{I}$ and the specific inhibitory increased with increasing concentration.So we can conclude that the inhibitory effect of halides ions is not a proper salt effect and it is an instance of specific ionic effect, because when we used a very high concentration of potassium sulphate the decrease in the rate constant is much less than in the case of any halide ion.

It is obvious from Tables (3) and (4) that in the presence of potassium sulphate, the value of the rate constant $\mathrm{k}_{\mathrm{O}}$ first decreases with time i.e. the salt effect is negative, reaches a minimum and then increases again which indicates that the reaction becomes auto-catalytic in the later stages. This behavior can be explained on the assumption that potassium sulphate acts as an inhibitor, so the auto-catalytic nature of the reaction does not appear in the initial stages because $\mathrm{K}_{2} \mathrm{SO}_{4}$ is formed in the reaction mixture, but after some time when it is decomposed by potassium peroxydisulphate, the reaction again becomes auto-catalytic.

From Table (6), Figure (3) it is obvious that electrolytes and non-electrolytes have a catalyzing influence on the thermal decomposition of potassium peroxydisulphate in the following order

$$
\mathrm{HCl}>\mathrm{KCl}>\mathrm{H}_{2} \mathrm{SO}_{4}>\mathrm{K}_{2} \mathrm{SO}_{4}>\text { Urea. }
$$

The catalyzing influence of $\mathrm{HCl}$ and $\mathrm{H}_{2} \mathrm{SO}_{4}$ may be mainly due to the $\mathrm{H}^{+}$ion, which may catalyze the reaction by the following steps :

$$
\begin{gathered}
\mathrm{SO}_{4}^{--}+\mathrm{H}^{+} \leftrightarrow \mathrm{HSO}_{4}^{-} \\
\mathrm{HSO}_{4}^{-}+\mathrm{H}_{2} \mathrm{O} \leftrightarrow \mathrm{HSO}_{4}^{-}+\mathrm{OH}^{-}+\mathrm{H}^{+}
\end{gathered}
$$

Tables (7) and (8) show the catalytic influence of mercuric chloride on the thermal decomposition of peroxydisulphate and it may be due to the production of other chain carriers as a result of the interaction between $\mathrm{HSO}_{4}^{-}$and $\mathbf{H g}$ ion, which may bring about the thermal decomposition of peroxydisulphate as shown by the following steps(Vasudeva, 1969):

$$
\begin{aligned}
\mathrm{HSO}_{4}^{-}+\mathrm{Hg}^{++} & \rightarrow \mathrm{HSO}_{4}+\mathrm{Hg}^{+} \\
\mathrm{Hg}^{+}+\mathrm{SO}_{4}{ }^{2-} & \rightarrow \mathrm{Hg}+\mathrm{SO}_{4}^{-} \\
\mathrm{Hg}+\mathrm{Hg}^{+} & \rightarrow \mathrm{Hg}_{2}{ }^{++} \\
\mathrm{HSO}_{4}^{-}+\mathrm{SO}_{4}{ }^{2-}+\mathbf{2 H g}^{++} & \rightarrow \mathrm{HSO}_{4}+\mathrm{SO}_{4}^{-}+\mathrm{Hg}_{2}{ }^{++}
\end{aligned}
$$

This require the reduction of mercuric chloride to mercurous chloride, and this has actually been observed that as the concentration of $\mathbf{H g}^{++}$ions increase, the catalytic influence increases

\section{References}

Bartlett, P. D., \& Cotman, J. D. (1949). J. Amer. Chem. Soc., 71, 1419.

Fronaeus, S., \& Ostman, C. O., (1955). The Kinetics and Mechanism of the Reaction between Cerium(III) and Persulphate. Acta. Chem. Scand., 9, 902. http://dx.doi.org/10.3891/acta.chem.scand.09-0902 
Green, L., \& Mason, D. O. (1910). CCXIX.-The dynamics of the decomposition of persulphuric acid and its salts in aqueous solution. J. Chem . Soc., 97, 2083. http://dx.doi.org/10.1039/ct9109702083

Kolthoff, I. M, \& Miller, I. K., (1951). The Chemistry of Persulfate. I. The Kinetics and Mechanism of the Decomposition of the Persulfate Ion in Aqueous Medium. J. Amer.Chem. Soc, 73, 3055. http://dx.doi.org/10.1021/ja01151a024

Levi, M. G., Migliorini, E., \& Gazz, A. (1963). Chim Ltal., 36(ii), 599.

Levitt, L.S, (1953). A New Mechanism For Persulphate Oxidations. Canad. J. Chem, $31,915$. http://dx.doi.org/10.1139/v53-122

Morgan, J. L., \& Christ, R. H., (1927). The Photochemical Decomposition Of Potassium Persulfate II. J. Amer. Chem. Soc., 49, 338-961. http://dx.doi.org/10.1021/ja01401a004

Rosin, J. (1946). Reagents Chemicals and standards (2nd ed.). New. York: D. van Nostrand. CO. Inc. p. 349.

Vasudeva, W. C. (1969). Ph. D thesis, Fac. of Science, U. Of K. 